\title{
Analysis of Voltage Unbalance and Energy Loss in Residential Low Voltage Distribution Systems with Rooftop Photovoltaic Systems
}

\author{
Rattanaprapa Charoenwattana ${ }^{1,2}$, and Umarin Sangpanich ${ }^{1, *}$ \\ ${ }^{1}$ Green-Smart Energy Technology (G-SET) Research Group, \\ Faculty of Engineering at Sriracha, Kasetsart University Sriracha Campus, Thailand \\ ${ }^{2}$ Provincial Electricity Authority (PEA), Thailand
}

\begin{abstract}
This paper investigates effects of voltage unbalance and energy losses due to the connection of rooftop photovoltaic systems in a low voltage distribution system of a housing estate, which has light loads during daytime. The paper presents a case study of a real distribution power system of housing estate in Thailand. Voltage unbalance and energy losses were simulated by using system characteristic and load data from GIS database of PEA with the DIgSILENT Power Factory program. The key findings of our analysis are as follows. Firstly, the number of installable 1-phase rooftop PV systems varies directly with load density. Secondly, the number of installed 1-phase rooftop PV systems can be increased if the installation locations are closer to the transformer. For 3-phase rooftop PV systems, their installations do not have any effects on the voltage unbalance. Furthermore, system energy loss relates to the load density and PV system installation locations in the same way as the voltage unbalance. The key implication of our study is that the installation of 1-phase rooftop PV system should be granted based on a careful consideration of the installation location and the load density.
\end{abstract}

Keywords: Installation, load density, minimum distribution, system energy.

\section{Introduction}

Three-phase voltage unbalance occurs when phase or line voltages are different from the nominal balanced situation. The voltage unbalance at terminals causes high current unbalance in three phase wye systems. It may decrease efficiency and lifetime of 3-phase transformers, motors and other loads. Furthermore, energy losses of systems can be increased because unbalanced current will flow in neutral lines. Voltage unbalance is caused by large and/or unequal distribution of 1-phase generation and/or load. At present, 1-phase grid-connected rooftop photovoltaic (PV) systems are widely installed by residential customers because of encouraging policies in many countries.

A rooftop PV system is an alternative clean energy system installed on the rooftop of a residential or commercial building. In Thailand, rooftop PV systems on residential building

*Corresponding author: umarin@eng.src.ku.ac.th 
normally are 1-phase systems and have a capacity of below $10 \mathrm{kWp}$, while those systems on commercial buildings are 3-phase systems and have a capacity of $10 \mathrm{kWp}$ to $1 \mathrm{MWp}$ [1]. A rooftop grid-connected PV system generates power to load of a building and to a distribution system during the day. In May 2019, the Thai government has a policy to encourage rooftop PV installation of $100 \mathrm{MWp}$ by accepting to buy excessive power

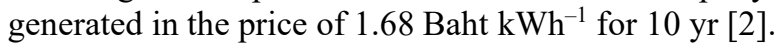

According to [3], increase or decrease of voltage unbalance in a radial low voltage residential urban distribution system depends on sizing and locating of PV systems and load demand. Rooftop PV systems are installed at only 1-phase in a 3-phase and four-wires distribution system at light load condition leading to the impact of voltage unbalance $[4,5]$. Because of the increase of rooftop PV systems, the maximum allowable number of gridconnected PVs in European and UK low voltage (LV) distribution networks was predicted based on voltage imbalance standard conditions [6].

This study investigated voltage unbalance and power loss issues due to the installation of rooftop PV systems in a LV distribution system of real housing estates. Thai housing estates normally have 50 households to 500 households built close together. Additionally, in Thailand, the number of rooftop PV systems within a single LV distribution system is regulated to be less than $15 \%$ of distribution transformer rating [7]. The LV distribution systems in Thai housing estates are short-distance systems because houses are close to one another. Loads within these systems are light during daytime. This research used real circuits and all parameters from the Geographic Information System (GIS) database of Provincial Electricity Authority (PEA). The voltage unbalance and power loss were calculated by using the DIgSILENT Power Factory program.

\section{Theory}

\subsection{Voltage unbalance}

Rooftop PV systems are connected with three-phase LV distribution system presented in Figure 1. Most rooftop PV systems of lower than $10 \mathrm{kWp}$ are 1-phase systems. A 1-phase rooftop PV residential system will be installed based on the phase of a load. The voltage unbalance may occur in a LV distribution system if the installation is not planned. Furthermore, a poor or illegal PV installation can make a LV distribution system having low power quality.

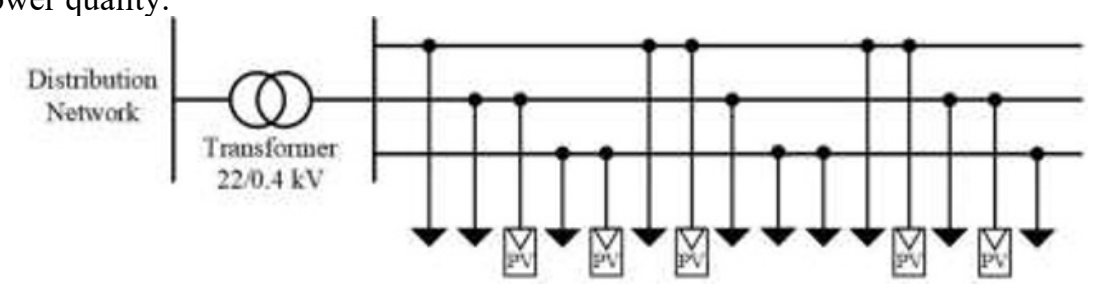

Fig. 1. Rooftop PV systems installed in a 3-phase LV distribution system.

Voltage unbalance can happen at any point throughout a 3-phase distribution system. The Percent Voltage Unbalance (PVU) is defined by the National Electrical Manufacturers Association (NEMA) as follows, in Equation (1) [8]:

$$
P V U=\left(M A X\left(V_{\mathrm{AB}}-V_{\mathrm{avg}}, V_{\mathrm{BC}}-V_{\mathrm{avg}}, V_{\mathrm{CA}}-V_{\mathrm{avg}}\right) / V_{\mathrm{avg}}\right) * 100
$$

where $\mathrm{V}_{\mathrm{AB}}$ is voltage between phase $\mathrm{A}$ and phase $\mathrm{B}(\mathrm{V})$, 
$\mathrm{V}_{\mathrm{BC}}$ is voltage between phase $\mathrm{B}$ and phase $\mathrm{C}(\mathrm{V})$,

$\mathrm{V}_{\mathrm{CA}}$ is voltage between phase $\mathrm{C}$ and phase $\mathrm{A}(\mathrm{V})$,

$\mathrm{V}_{\text {avg }}$ is average phase voltage calculated by Equation (2):

$$
V_{\text {avg }}=\left(V_{\mathrm{AB}}+V_{\mathrm{BC}}+V_{\mathrm{CA}}\right) / 3
$$

In Thailand, the electricity authorities follow the IEC standard to ensure that the PVU is lower than $2 \%$.

\subsection{Power loss in a feeder}

Voltage unbalance causes imbalance current flows in a neutron line of a 3-phase 4-wire system leading to power loss in a neutral line. Therefore, power loss will increase in a distribution system. Power loss can be calculated by Equation (3) [9]:

$$
P_{\text {loss }}=I_{\mathrm{A}}^{2} R_{\mathrm{A}}+I_{\mathrm{B}}^{2} R_{\mathrm{B}}+I_{\mathrm{C}}^{2} R_{\mathrm{C}}+I_{\mathrm{N}}^{2} R_{\mathrm{N}}
$$

where $I_{A}, I_{B}, I_{C}$ and $I_{N}$ are currents in line as phase $A, B, C$ and $N$, respectively.

$R_{A}, R_{B}, R_{C}$ and $R_{N}$ are resistance values.

\section{Method}

This paper analyzes the impact of voltage unbalance and power loss causing by many rooftop PV systems installed in a LV distribution system of housing estate at which there is light load during daytime. Our research approach consists of several key steps:

i). Study voltage unbalance and power loss in distribution systems.

ii). Simulate 1-phase and 3-phase rooftop PV systems installed in LV distribution systems of housing estates by using real data from the GIS database and selecting the installation of rooftop PV systems in each phase at different load densities. The proportion of rooftop PV system penetration in a LV distribution system can be calculated by the ratio of installed PV power capacity and the transformer rated power.

iii). Analyze and evaluate the impact of rooftop PV systems in LV distribution systems of housing estates on voltage unbalance and power loss issues.

\section{Case study}

\subsection{Residential low voltage distribution system}

This paper presents analysis results of the unbalance voltage and energy loss of a housing estate in Chonburi province, Thailand. The system has a rated LV distribution transformer of $250 \mathrm{kVA}, 22 / 0.4 \mathrm{kV}$. The housing estates under this study consists of 92 households and a total system line length of approximately $1.449 \mathrm{~km}$ as shown in Figure 2. A transformer is located at $\mathrm{S}$ point.

The system circuit has two main lines, namely (i) the high load density of $82.67 \%$ total system load in the long line of $1.182 \mathrm{~km}$ and (ii) the light load density of $17.33 \%$ total system load in the short line of $0.176 \mathrm{~km}$ as shown in Table 1. Rooftop PV systems of $2.5 \mathrm{kWp}$ to $10 \mathrm{kWp}$ were assumed to be installed for four case studies, namely the end of high load density and long line (X1) and (X5), the middle of high load density and long line (X2), the nearest transformer position (X3) and the end of light load density and short line (X4) and (X6). However, at the end of high load density and long line section, X1 has a 
voltage unbalance more than X5. Therefore, X1 location was used to be a representative at the end of high load density and long line section. At the end of light load density and short line section, X4 has a voltage unbalanced more than X6. Thus, X4 location was selected to be a representative at the end of light load density and short line section.

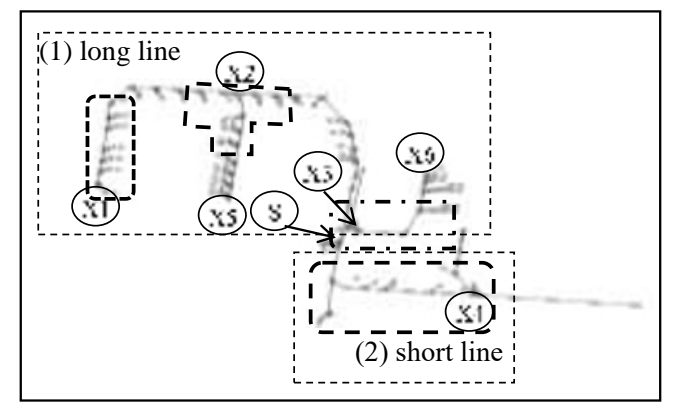

Fig. 2. The real residential distribution system circuit of a housing estate and installation locations of rooftop PV systems.

Table 1. Voltage unbalance at locations before installation of rooftop PV systems.

\begin{tabular}{|c|c|c|c|c|c|c|c|c|c|}
\hline \multirow{2}{*}{\multicolumn{2}{|c|}{ Location }} & \multicolumn{3}{|c|}{ Voltage (pu) } & \multirow{2}{*}{ PVU } & \multirow{2}{*}{$\begin{array}{c}\text { Distan } \\
\text { ce } \\
\text { from } \\
S(m)\end{array}$} & \multicolumn{3}{|c|}{$\begin{array}{c}\text { Load density }\left(\mathrm{W} \mathbf{m}^{-1}\right) \\
\text { at midday }\end{array}$} \\
\hline & & $\mathbf{V}_{\mathrm{AB}}$ & $\mathbf{V}_{\text {BC }}$ & $\mathbf{V}_{\mathbf{C A}}$ & & & $\mathbf{A}$ & B & C \\
\hline \multirow{2}{*}{$\begin{array}{l}\text { The end } \\
\text { of high } \\
\text { load } \\
\text { density } \\
\text { and long } \\
\text { line }\end{array}$} & $\mathrm{X} 1$ & 0.9716 & 0.9957 & 0.9767 & 1.463 & 271.14 & 73.26 & 0.00 & 12.42 \\
\hline & $\mathrm{X} 5$ & 0.9720 & 0.9959 & 0.9773 & 1.441 & 223.89 & 88.71 & 0.00 & 7.52 \\
\hline \multicolumn{2}{|c|}{$\begin{array}{l}\text { The middle of } \\
\text { high load } \\
\text { density and } \\
\text { long line (X2) }\end{array}$} & 0.9742 & 0.9959 & 0.9794 & 1.295 & 146.82 & 57.84 & 0.00 & 11.46 \\
\hline \multicolumn{2}{|c|}{$\begin{array}{l}\text { The nearest } \\
\text { transformer } \\
\text { position }(\mathrm{X} 3)\end{array}$} & 0.9882 & 0.9969 & 0.9942 & 0.490 & 16.10 & 139.89 & 0.00 & 0.00 \\
\hline \multirow{2}{*}{$\begin{array}{l}\text { The end } \\
\text { of light } \\
\text { load and } \\
\text { short line }\end{array}$} & $\mathrm{X} 4$ & 0.9872 & 0.9972 & 0.9928 & 0.527 & 112.69 & 54.92 & 0.00 & 14.98 \\
\hline & $\mathrm{X} 6$ & 0.9873 & 0.9958 & 0.9937 & 0.501 & 85.76 & 26.26 & 52.47 & 19.69 \\
\hline \multicolumn{2}{|c|}{$\begin{array}{c}\text { Transformer } \\
(\mathrm{S})\end{array}$} & 0.9887 & 0.9974 & 0.9944 & 0.482 & - & - & - & - \\
\hline \multicolumn{6}{|c|}{ Total main feeder } & 856.40 & 47.66 & 5.26 & 7.87 \\
\hline \multicolumn{6}{|c|}{ Total main feeder and sub feeders } & $\begin{array}{c}1 \\
449.00\end{array}$ & 28.17 & 3.11 & 4.65 \\
\hline
\end{tabular}

\subsection{Load profile}

Daily load demand of residential low voltage distribution system for a housing estate illustrated in Figure 3 was used as an annual load profile to calculate unbalance voltage and 
energy loss. The worst case of voltage unbalance appearing at midday having the total system load of $52.06 \mathrm{~kW}$ (20.8 $2 \%$ of rated transformer) was studied as shown in Table 1, at phase A of about $40.82 \mathrm{~kW}(78.4 \%)$, phase B of about $4.5 \mathrm{~kW}(8.65 \%)$ and phase $\mathrm{C}$ of about $6.74 \mathrm{~kW}(12.95 \%)$ in 2016.

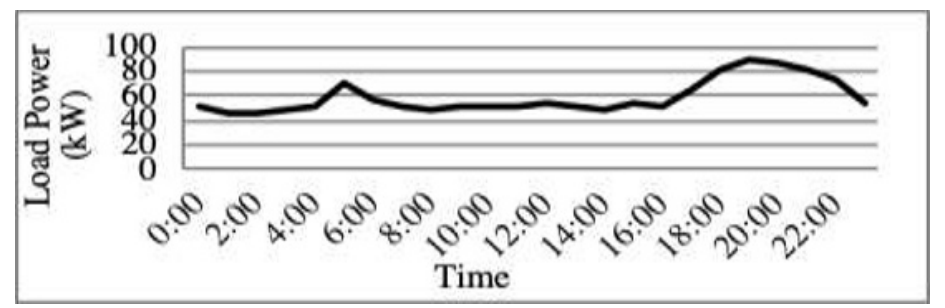

Fig. 3. Daily load of residential low voltage distribution system.

\subsection{Rooftop PV system sizes}

Single-crystalline silicon modules of $100 \mathrm{Wp}$ were used with an efficiency of $14.5 \%$ and a 25 -yr guarantee. The optimum slope angle of $13^{\circ}$ facing the South should be installed to get the annual maximum output energy for this housing estate. PV power was calculated from Photovoltaic Geographical Information System (PVGIS) by using data of solar radiation on an inclined surface, a PV array area and PV system efficiency. Hourly solar radiation was measured at Chonburi province in 2016. The sunshine duration was eight sunshine-h $\mathrm{d}^{-1}$ and annual average solar energy was about $5.66 \mathrm{kWh} \mathrm{m}^{-2} \mathrm{~d}^{-1}$ [10]. Rooftop PV system sizes of $2.5 \mathrm{kWp}$ to $10 \mathrm{kWp}$ were simulated in each location in Figure 2.

\section{Results and discussion}

This paper examines the unbalance voltage and energy loss of 1-phase and 3-phase rooftop PV system installation in the residential LV distribution system, for which results and discussions are as follows:

\subsection{Voltage unbalance for installation of 1-phase rooftop PV systems}

There are two mains finding from the simulation results in Table 2 and Figure 4 to Figure 6.

First, A phase having the higher load density, the higher rooftop PV system installation can be and can reduce the PVU. The maximum number of rooftop PV systems can be installed at Phase A having the highest load demand. Moreover, the rooftop PV system installed at X1 in Phase A can decrease the PVU to $0.815 \%$ (from $1.463 \%$ without PV system installation). On the other hand, Phase B is connected with the lowest load density of $5.26 \mathrm{~W} \mathrm{~m}^{-1}$ and then it can be allowed to install a lowest PV capacity of $2 \%$ transformer rating (about $5 \mathrm{kWp}$ ).

Second, the number of installed rooftop PV systems can be increased if the installation locations are closer to the transformer. The highest capacities of rooftop PV systems can be installed at the nearest transformer position (X3). Rooftop PV systems are able to be installed at the middle of long line (X2) and at the end short line (X4) more than at the end of long line (X1).

Based on our findings and the regulations by the electricity authorities in Thailand which state that (i) the Percent Voltage Unbalance (PVU) must be lower than $2 \%$ (according to the IEC standard) and (ii) the number of PV grid-connected systems must be lower than $15 \%$ transformer rating, the electricity authorities should take into account the 
system installation location when issuing the permit for 1-phase rooftop PV systems. Specifically, for installation locations that are close to the transformer, the authorities can allow higher number of 1-phase rooftop PV systems whereas, for the installation locations that are far from the transformers, the authorities need to examine the total capacity of installed 1-phase rooftop PV systems in each phase before issuing the permission.

Furthermore, the scattering rooftop PV system installation of $5 \%$ transformer rating was simulated at each location, namely X1, X2 and X4. Rooftop PV systems can be installed at Phase A (the highest load density) without the voltage unbalance impact. In the other hand, if they would be installed at Phase B or Phase C, the PVU would be higher than $2 \%$ at $\mathrm{X} 1$ and $\mathrm{X} 2$.

Table 2. The percentage of rooftop PV system installation at the PVU of $2 \%$

\begin{tabular}{|c|c|c|c|c|c|c|}
\hline \multirow{2}{*}{ Locations } & \multicolumn{3}{|c|}{ Load (kW) } & \multicolumn{2}{c|}{ \% Installation of rooftop PV systems } \\
\cline { 5 - 7 } & A & B & C & A & B & C \\
\hline $\begin{array}{c}\text { The end of high load } \\
\text { density and long line (X1) }\end{array}$ & \multirow{2}{*}{34.63} & 4.50 & 5.06 & $18.63 \%$ & $4.49 \%$ & $11.45 \%$ \\
\hline $\begin{array}{c}\text { The middle of high load } \\
\text { density and long line (X2) }\end{array}$ & $34.14 \%$ & $2.14 \%$ & $5.96 \%$ \\
\hline $\begin{array}{c}\text { The nearest transformer } \\
\text { position (X3) }\end{array}$ & & & $77.40 \%$ & $26.03 \%$ & $31.53 \%$ \\
\cline { 5 - 7 } $\begin{array}{c}\text { The end of light load and } \\
\text { short line (X4) }\end{array}$ & 6.19 & 0.00 & 1.69 & $24.03 \%$ & $13.17 \%$ & $17.83 \%$ \\
\hline
\end{tabular}

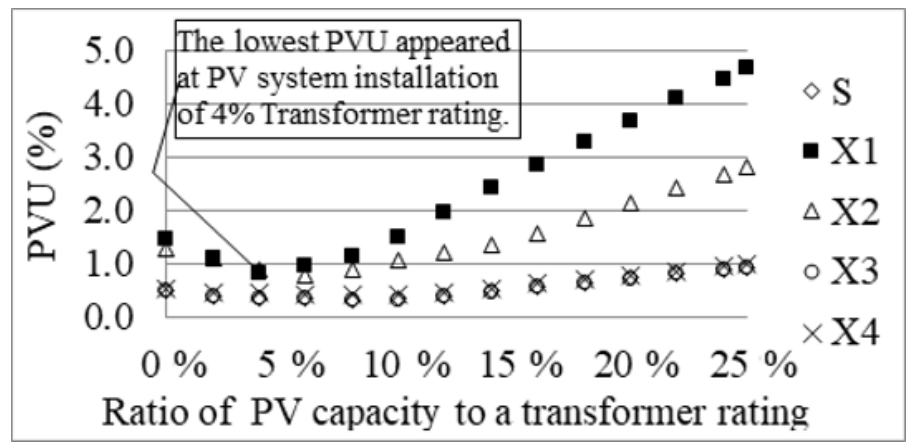

Fig. 4. The PVU for installation of 1-phase rooftop PV systems at X1 in Phase A.

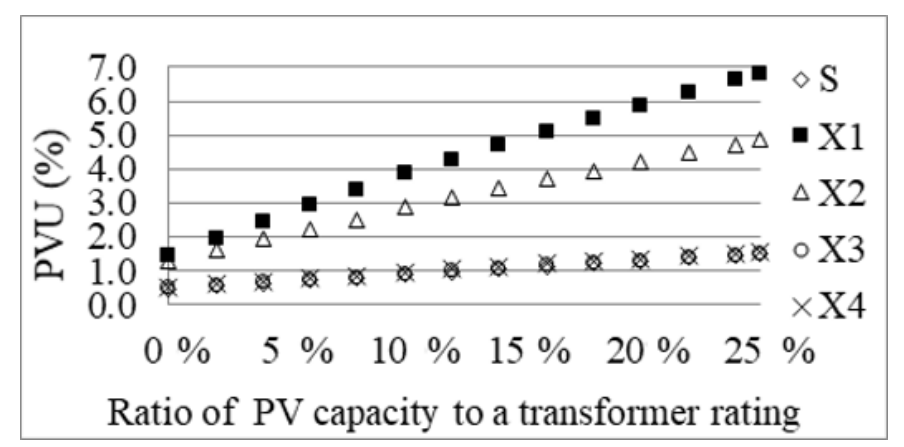

Fig. 5. The PVU for installation of 1-phase rooftop PV systems at X1 in Phase B. 


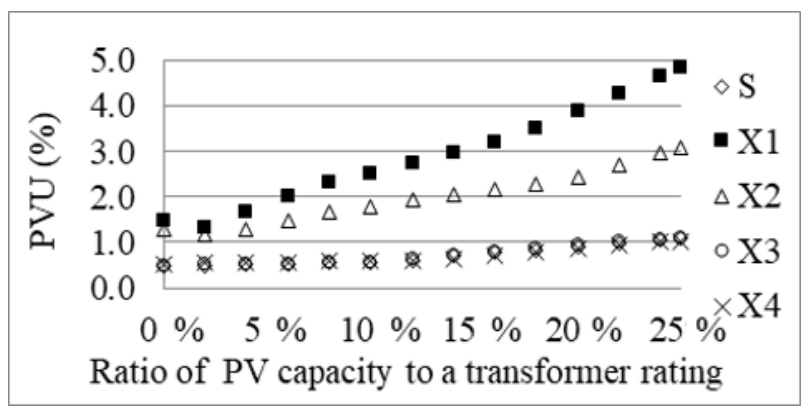

Fig. 6. The PVU for installation of 1-phase rooftop PV systems at X1 in Phase C.

\subsection{Voltage unbalance for installation of 3-phase rooftop PV systems}

The simulation results show that 3-phase rooftop PV systems can be installed at all locations in the feeder without the increase of voltage unbalance. Consequently, it is possible for the authorities to issue the permits for all cases as they do not have any effects on the voltage unbalance including the overvoltage.

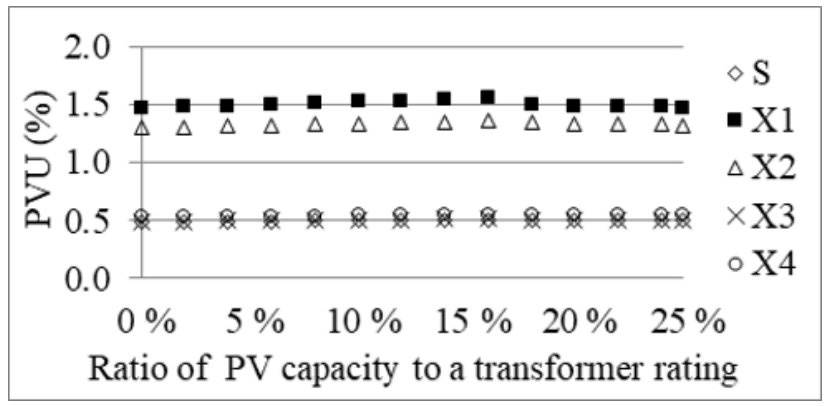

Fig. 7. Voltage unbalance due to 3-phase rooftop PV systems installation at each location.

\subsection{Energy Loss}

Voltage unbalances will generate extra power loss and decrease system efficiency because of increasing current flows in the neutral line of a LV distribution system. Many 1-phase rooftop PV systems installed in the residential LV distribution system can affect the voltage unbalance as the result and discussion in 5.1. Considering the results of system energy loss ( $E_{\text {loss }}$ ) in all cases of 1-phase PV systems, it was found that the system energy loss relates to the load density and PV system installation location in the same way as the voltage unbalance. The total system energy losses were investigated during day time at 7 am to $6 \mathrm{pm}$, as shown in Figure 8 and Table 3. In this case of system without rooftop PV systems installed, the system energy loss is approximately $10.25 \mathrm{kWh}$. If rooftop PV systems are installed at Phase B and C, the energy loss will be increased. Alternatively, rooftop PV systems can be installed at X1 in Phase A and the energy loss can be decreased when PV capacities will be less than $12 \%$ transformer rating as shown in Figure 9.

Although, the installation of 3-phase PV systems will not affect the voltage unbalance, the installation at the end of light load and short line (X4) of above $15 \%$ transformer rating can increase the system energy loss to $11.63 \mathrm{kWh}$. Nevertheless, if 3-phase PV systems are installed diffusely, they can be installed about $20 \%$ transformer rating and energy loss can be reduced. 


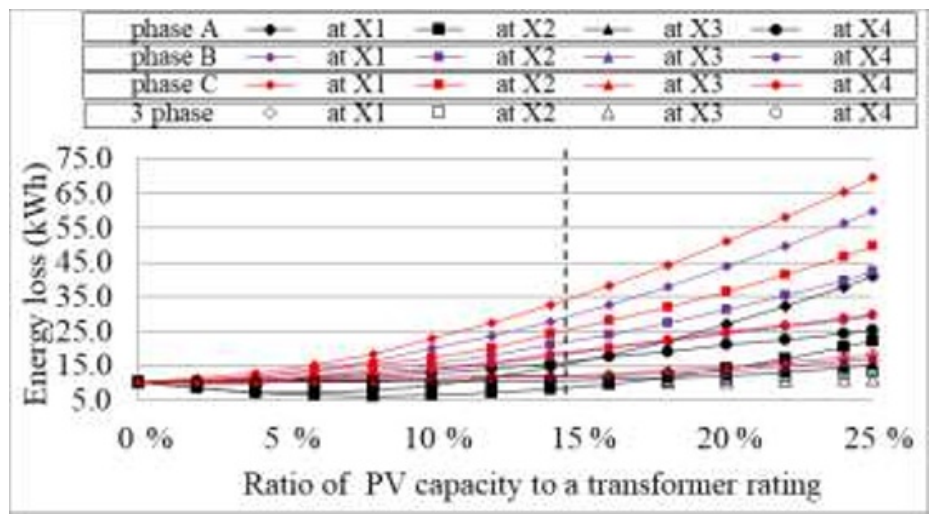

Fig. 8. Total energy loss of 1-phase and 3-phase rooftop PV system installation.

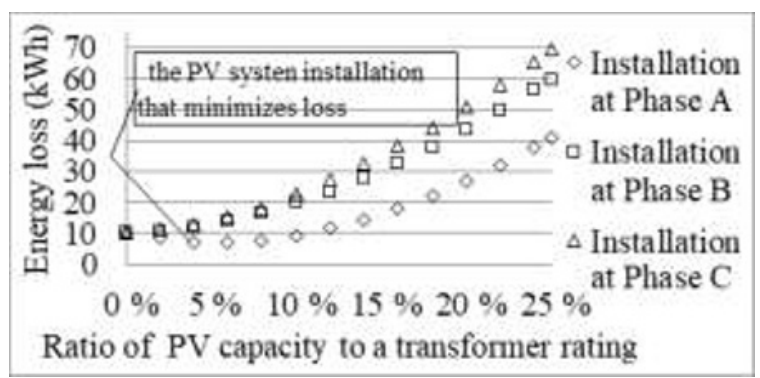

Fig. 9. Total energy loss of 1-phase rooftop PV system installation at X1.

Table 3. The percentage of rooftop PV system installation and the system energy loss.

\begin{tabular}{|c|c|c|c|c|c|}
\hline \multirow{2}{*}{ Installation Location } & \multirow{2}{*}{ Phase } & \multicolumn{2}{|c|}{ Minimum Eloss } & \multirow{2}{*}{$\begin{array}{c}\% P V \text { installation } \\
\text { (E } \text { E loss }>\text { E }_{\text {loss without }} \\
\text { PV systems) }\end{array}$} & \multirow{2}{*}{$\begin{array}{c}\text { Eloss of } 15 \% \% \\
\text { installation } \\
(\mathrm{kWh})\end{array}$} \\
\hline & & $\begin{array}{c}\% \mathrm{PV} \\
\text { installation }\end{array}$ & $\begin{array}{c}\text { Eloss }_{(\mathbf{k W h})} \\
(\mathrm{k} h{ }\end{array}$ & & \\
\hline \multirow{4}{*}{$\begin{array}{l}\text { The end of high load } \\
\text { density and long line } \\
\text { (X1) }\end{array}$} & A & 6 & 7.18 & 12 & 16.22 \\
\hline & B & 0 & 10.25 & 1 & 30.11 \\
\hline & $\mathrm{C}$ & 0 & 10.25 & 1 & 35.30 \\
\hline & $\mathrm{ABC}$ & 6 & 9.36 & 12 & 11.59 \\
\hline \multirow{4}{*}{$\begin{array}{l}\text { The middle of high } \\
\text { load density and long } \\
\text { line (X2) }\end{array}$} & $\mathrm{A}$ & 8 & 6.22 & 18 & 8.97 \\
\hline & B & 0 & 10.25 & 1 & 22.59 \\
\hline & $\mathrm{C}$ & 0 & 10.25 & 1 & 26.21 \\
\hline & $\mathrm{ABC}$ & 8 & 9.07 & 18 & 9.65 \\
\hline \multirow{4}{*}{$\begin{array}{c}\text { The nearest } \\
\text { transformer position } \\
\text { (X3) }\end{array}$} & A & 4 & 10.25 & 6 & 10.82 \\
\hline & B & 2 & 10.25 & 4 & 12.01 \\
\hline & $\mathrm{C}$ & 0 & 10.25 & 1 & 12.29 \\
\hline & $\mathrm{ABC}$ & 8 & 10.16 & 18 & 10.20 \\
\hline \multirow{4}{*}{$\begin{array}{l}\text { The end of light load } \\
\text { and short line (X4) }\end{array}$} & A & 2 & 9.91 & 6 & 16.60 \\
\hline & B & 0 & 10.25 & 1 & 18.94 \\
\hline & $\mathrm{C}$ & 0 & 10.25 & 1 & 19.37 \\
\hline & $\mathrm{ABC}$ & 4 & 10.23 & 6 & 11.63 \\
\hline \multirow{4}{*}{$\begin{array}{c}\mathrm{X} 1, \mathrm{X} 2, \mathrm{X} 4 \\
\text { (equally of each } \\
\text { location) }\end{array}$} & $\mathrm{A}$ & 10 & 6.26 & 20 & 7.70 \\
\hline & $\mathrm{B}$ & 0 & 10.25 & 1 & 19.18 \\
\hline & $\mathrm{C}$ & 0 & 10.25 & 1 & 22.12 \\
\hline & $\mathrm{ABC}$ & 10 & 9.06 & 20 & 9.48 \\
\hline
\end{tabular}




\section{Conclusions}

There are two main findings from the simulation results. Firstly, a phase having the higher load density, the higher rooftop PV system installation can be. Secondly, the number of installed rooftop PV systems can be increased if the installation locations are closer to the transformer. For the installation of 3-phase rooftop PV systems, it is possible for the authorities to issue the permits for all cases as they do not have any effects on the voltage unbalance. The total system energy losses were investigated during daytime at 7 am to 6 pm. The results show that system energy loss relates to the load density and PV system installation location in the same as the voltage unbalance. Consequently, the installation of 1-phase rooftop PV system should be granted based on the result of examining the installation location and the load density.

\section{References}

1. Department of Alternative Energy Development and Efficiency Ministry of Energy, Thailand implements Photovoltaic Support Programme and increases Renewable Energy Targets. [Online] from

http://weben.dede.go.th/webmax/sites/default/files/Thailand\%20implements\%20Photo voltaic\%20Support.pdf (2013) [Accessed on July 10th 2019].

2. Prachachat, $100 \mathrm{MW}$ solar public wake up a market for a manufacturer of a house parade on a solar roof top. [Online] from https://www.prachachat.net/economy/news302914. (2019) [Accessed on July 17th 2019].

3. F. Shahnia, R. Majumder, A. Ghosh, G. Ledwich, F. Zare, Sensitivity analysis of voltage imbalance in distribution networks with rooftop PVs. Proceedings of IEEE PES General Meeting, PES 2010. P. Traynor, (Eds.), IEEE Xplore, United States, 2010, p. 1-8. https://ieeexplore.ieee.org/abstract/document/5590149/

4. K.H. Chua, Y.S. Lim, J. Wong, P. Taylor, E. Morris, S. Morris, JEST, 10,1:16(2012). https://eprint.ncl.ac.uk/192883

5. C. Pansakul, K. Hongesombut, Analysis of voltage unbalance due to rooftop PV in low voltage residential distribution system. 2014 International Electrical Engineering Congress (iEECON). IEEE 2014, p. 1-4.

https://ieeexplore.ieee.org/abstract/document/6925883/

6. P. Trichakis, P.C. Taylor, P.F. Lyons, R. Hair, IET Renew. Power Gener., 2,4:249262(2008). https://ieeexplore.ieee.org/document/4610982

7. Provincial Electricity Authority (PEA). PEA grid code 2016. PEA, Bangkok, Thailand (2016). p. 7-19.

https://www.pea.co.th/Portals/0/Document/vspp/PEA\%20Interconnection\%20Code\% 202016.pdf

8. A. Von Jouanne, B. Banerjee, EEE Trans. Power Deliv., 16,4:782-790(2001). https://ieeexplore.ieee.org/abstract/document/956770/

9. K.H. Chua, Y.S. Lim, P. Taylor, S. Morris, J. Wong, EEE Trans. Power Deliv., 27,4:1783-1790(2012). https://ieeexplore.iee.org/abstract/document/6298991/

10. European Commission, Photovoltaic Geographical Information System. [Online] from https://re.jrc.ec.europa.eu/pvg_tools/en/tools.html\#TMY (2017). [Accessed on July 30th 2019]. 